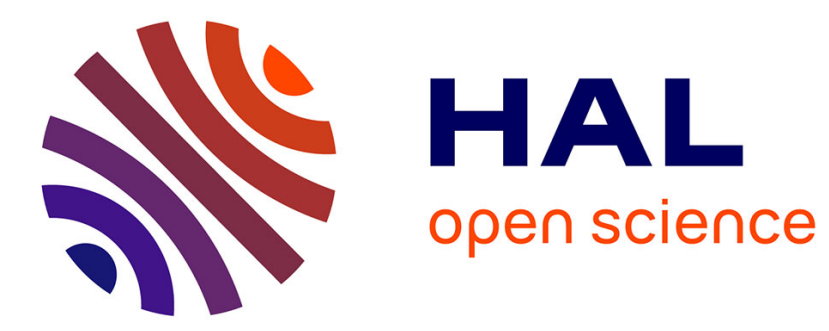

\title{
Hybrid polyoxometalate palladacycles: DFT study and application to the Heck reaction
}

\author{
Benoît Riflade, Julie Oble, Ludwig Chenneberg, Etienne Derat, Bernold \\ Hasenknopf, Emmanuel Lacôte, Serge Thorimbert
}

\section{- To cite this version:}

Benoît Riflade, Julie Oble, Ludwig Chenneberg, Etienne Derat, Bernold Hasenknopf, et al.. Hybrid polyoxometalate palladacycles: DFT study and application to the Heck reaction. Tetrahedron, 2013, 69 (27-28), pp.5772-5779. 10.1016/j.tet.2013.03.045 . hal-01234021

\section{HAL Id: hal-01234021 https://hal.sorbonne-universite.fr/hal-01234021}

Submitted on 26 Nov 2015

HAL is a multi-disciplinary open access archive for the deposit and dissemination of scientific research documents, whether they are published or not. The documents may come from teaching and research institutions in France or abroad, or from public or private research centers.
L'archive ouverte pluridisciplinaire HAL, est destinée au dépôt et à la diffusion de documents scientifiques de niveau recherche, publiés ou non, émanant des établissements d'enseignement et de recherche français ou étrangers, des laboratoires publics ou privés. 


\title{
Hybrid polyoxometalate palladacycles: DFT study and application as catalysts for the Heck reaction
}

\author{
Benoît Riflade $^{\mathrm{a}}$, Julie Oble $^{\mathrm{a}}$, Ludwig Chenneberg, ${ }^{\mathrm{a}}$ Etienne Derat $^{\mathrm{a} *}$, Bernold Hasenknopf $^{\mathrm{a} *}$, \\ Emmanuel Lacôte ${ }^{\mathrm{a}, \mathrm{b}}$, Serge Thorimbert ${ }^{\mathrm{a} *}$ \\ ${ }^{a}$ UPMC Sorbonne Universités. Institut Parisien de Chimie Moléculaire. UMR CNRS 7201. 4 place Jussieu, 75005 Paris, France \\ ${ }^{b}$ Université de Lyon, Institut de chimie de Lyon. UMR 5265 CNRS-Université Lyon I-ESCPE Lyon. 43 Bd du 11 novembre 1918, 69616 \\ Villeurbanne, France
}

\begin{abstract}
The phosphovanadotungstate polyanion $\left[\mathrm{P}_{2} \mathrm{~W}_{15} \mathrm{~V}_{3} \mathrm{O}_{62}\right]^{9-}$ is a powerful support to stabilize palladacycles conjugated to the inorganic framework via an organic ligand. The insertion can be directed toward $\mathrm{sp}^{2}$ or $\mathrm{sp}^{3} \mathrm{C}-\mathrm{H}$ insertion upon appropriate choice of the substitution pattern on the organic ligand. DFT modeling indicates that the strong withdrawing effect of the POM transmitted through the conjugated carbonyl was responsible for this easy insertion. The palladacycles led to the formation of stilbene via a Mizoroki-Heck reaction. However it is likely that the POMs act as Pd-reservoirs for the formation of nanoparticles.
\end{abstract}

Keywords: Hybrid Polyoxometallate; Catalysis; Heck reaction; C-H insertion; Palladacycles

\section{Introduction}

Polyoxometalates (POMs) are anionic clusters composed of transition metals at their highest oxidation state linked by oxido ligands. Most of these structures contain metal atoms from group 5 or 6 (Molybdenum, Tungsten, Vanadium, Niobium) as is the case in the most famous Anderson, Linqvist, Keggin and Dawson families. ${ }^{1}$ However, inclusion of noble metal ions ( $\mathrm{Ru}, \mathrm{Rh}, \mathrm{Pd}, \mathrm{Pt}$, Ir, Os, $\mathrm{Au}, \mathrm{Ag}$ ) inside or outside these clusters has attracted growing attention because it is a way to increase the structural diversity in POM chemistry, as well as to add different redox and catalytical properties, thus potentially enhancing existing reactivities or accessing new ones. ${ }^{2}$

Palladium-substituted POMs have gained a special prominence since the seminal Knoth et al. 1986 report, which described the first synthesis of a Pd-containing POM. ${ }^{3}$ Reaction of the lacunary Keggin POM Na ${ }_{8} \mathrm{H}\left[\mathrm{A}, \alpha-\mathrm{W}_{9} \mathrm{PO}_{34}\right]$ with divalent $\mathrm{Pd}$ cations afforded the desired heteropolyanion $\left[\mathrm{Pd}_{3}\left(\mathrm{~A}, \alpha-\mathrm{W}_{9} \mathrm{PO}_{34}\right)_{2}\right]^{12-}$, as suggested by elemental analyses and analogy to other divalent transition metal cations. However, no structure could be obained. The group of Lawrance reported the first crystal structure of a Pd-substituted POM. Reaction of an aqueous solution of sodium tungstate and potassium tetrachloropalladate at $\mathrm{pH} 5.5$ delivered $\mathrm{K}_{2} \mathrm{Na}_{6}\left[\mathrm{Pd}_{2} \mathrm{~W}_{10} \mathrm{O}_{36}\right] \cdot 22 \mathrm{H}_{2} \mathrm{O}$ as chocolate-brown crystals. Both square planar Pd ions are linking two monolacunary Linqvist units $\left(\mathrm{W}_{5} \mathrm{O}_{18}\right)^{6-}$ by a pairwise connection of the terminal oxygens of the lacuna. ${ }^{4}$

Since these pioneering works, several research groups have focused on the synthesis and characterization of new palladium substituted polyoxometalates (Figure 1), ${ }^{5}$ in particular the group of Kortz. ${ }^{6}$ The palladium (II) ions in these structures are generally coordinated in a square planar geometry to oxygens of lacunary Keggin, Anderson or Dawson POMs.

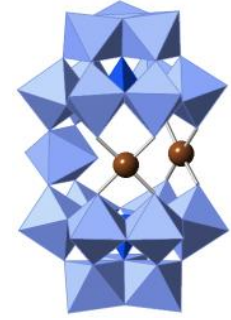

Kortz (2004)

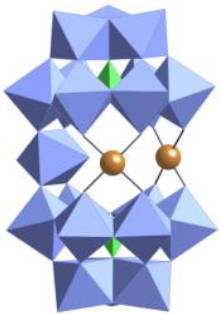

Proust (2009)

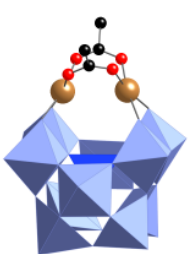

Mizuno (2012)

Figure 1 Examples of polyoxometalates containing palladium: $\left[\mathrm{Cs}_{2} \mathrm{~K}\left(\mathrm{H}_{2} \mathrm{O}\right)_{7} \mathrm{Pd}_{2} \mathrm{WO}\left(\mathrm{H}_{2} \mathrm{O}\right)\left(A-\alpha-\mathrm{SiW}_{9} \mathrm{O}_{34}\right)_{2}\right]^{9-}(\mathrm{left}) ;\left[\mathrm{Pd}_{2}\left\{\mathrm{WO}\left(\mathrm{H}_{2} \mathrm{O}\right)\right\}\{A, \alpha-\right.$ $\left.\left.\mathrm{PW}_{9} \mathrm{O}_{34}\right\}_{2}\right]^{10-}$ (center); $\left[\gamma-\mathrm{H}_{2} \mathrm{SiW}_{10} \mathrm{O}_{36} \mathrm{Pd}_{2}(\mathrm{OAc})_{2}\right]^{4-}$ (right)

In 2003, one of us introduced a new type of Pd-POM mixed systems. $\mathrm{PdCl}_{2}$ was covalently linked to a functional organo-POM containing pyridine appendages. ${ }^{7}$ The coordination of the palladium to both pyridines of the Anderson POM $\left[\mathrm{MnMo}_{6} \mathrm{O}_{18}\left\{\left(\mathrm{OCH}_{2}\right)_{3} \mathrm{CNHCO}\left(4-\mathrm{C}_{5} \mathrm{H}_{4} \mathrm{~N}\right)\right\}_{2}\right]^{3-}$ induced the formation of a coordination polymer that transformed 
into an anisotropic gel. That same year, the Neumann group used the same strategy of POM-grafted ligands to tune the electronic properties of metallo-salen derivatives (Figure 2, left). ${ }^{8}$ They showed that the "polyoxometalate exerts a significant intramolecular electronic effect on the metallosalen moiety leading to formation of an oxidized metallosalen moiety", suggesting that there might be a "delocalized hole" at the metal center, which is specific to POM-salen hybrids.

Several additional examples of POM-Pd hybrids have been described with different kind of linkages leading to new complexes. ${ }^{9}$ An illustrative example was published by the Bonchio group, who showed that Keggin-based hybrid bisNHC compounds were powerful catalysts for carbon-carbon coupling and dehalogenation reactions (Figure 2 , right). ${ }^{9 \mathrm{a}}$ The POM protects the reactive Pd center from decomposition via formation of nanoparticles, resulting in high TONs.

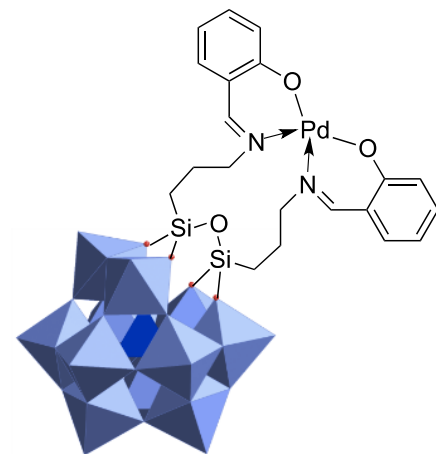

Neumann et al., 2003

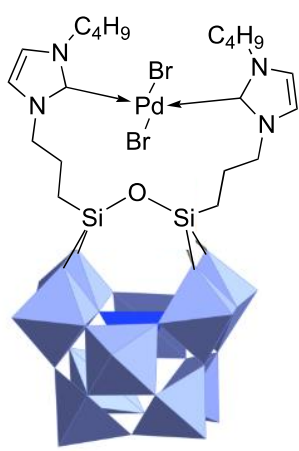

Bonchio et al., 2010

Figure 2: Example of covalent POM-Pd hybrids: $\left[\mathrm{Pd}\left(\mathrm{salen}-\left(\mathrm{CH}_{2}\right)_{3} \mathrm{Si}\right)_{2} \mathrm{O}\left(\mathrm{SiW}_{11} \mathrm{O}_{39}\right)\right]^{4-}($ left $) ;\left[\mathrm{PdBr}_{2}\left(\mathrm{C}_{10} \mathrm{H}_{17} \mathrm{~N}_{2} \mathrm{Si}\right)_{2} \mathrm{O}\left(\gamma-\mathrm{SiW}_{10} \mathrm{O}_{36}\right)\right]^{4-}$ (right)

The Neumann group very cleverly used ionic interactions to devise new cooperative Pd/POM bimetallic hybrid catalytic systems. $\mathrm{Pd}^{\mathrm{II}}$ (15-crown-5-phen) $\mathrm{Cl}_{2}-\mathrm{H}_{5} \mathrm{PV}_{2} \mathrm{Mo}_{10} \mathrm{O}_{40}$ was used to catalyze the Wacker oxidation of 1-alkenes using nitrous oxide as the terminal oxidant. ${ }^{10} \mathrm{~A}$ similar strategy was later employed by the Wang group for the heterogeneous aerobic oxidation of benzene. The ion pairing is crucial to understand the high activity by the proposed intramolecular electron transfer mechanism. ${ }^{11}$

Part of our interest in POMs chemistry consists in finding new modified POM-catalysts for organic reactions, mainly Lewis acidic ones. ${ }^{12}$ The conjugated diolamide-capped Dawson $\left[\mathrm{P}_{2} \mathrm{~W}_{15} \mathrm{~V}_{3} \mathrm{O}_{62}\right]^{9-}$ (1) phosphovanadotungstate family we introduced ${ }^{13}$ has proved adept at catalyzing the oxidation of sulfides with high chemoselectivity. ${ }^{14}$

We extended its potential by grafting picolinic amide derivatives onto (1). The latter hybrids could complex $\mathrm{Pd}(\mathrm{OAc})_{2}$, generating stable palladacycles 2-8 (Figure 3), and which were used as electrophilic catalysts in the allylation of aldehydes and imines. ${ }^{15}$

From the catalytic point of view, the Pd atom of $\mathbf{2}$ did not change oxidation state during the allylation reactions. We felt that new reactivities might be derived from exploiting the rich redox chemistry of palladium, especially given that the conjugated POM framework could accommodate electrons and stabilize higher oxidation states of Pd.

In the present article we first examined the competition between $\mathrm{C}-\mathrm{H}$ activation of a $\mathrm{sp}^{2}$ center $v s$. a $\mathrm{sp}^{3}$ carbon and used DFT modeling to understand better the easy formation of the POM-palladacycles. We then examined their behavior as catalysts for the Heck coupling. 


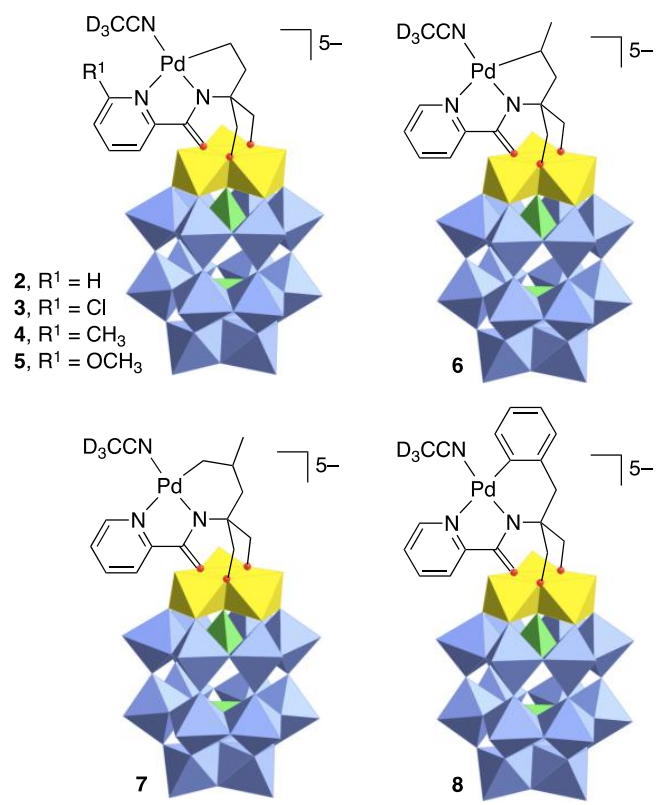

Figure 3: Structures of existing Pd-complexes of diolamide-capped Dawson $\left[\mathrm{P}_{2} \mathrm{~W}_{15} \mathrm{~V}_{3} \mathrm{O}_{62}\right]^{9}$ ion 1

\section{Results/Discussion}

\subsection{Preparation of picolinic diolamide-capped POMs}

The general scheme for the preparation of the hybrid ligands and palladacycles is presented in Scheme 1. The new diolamides 9-13 required for the study were prepared following our established procedure, by coupling of the corresponding carboxylic esters with the adequate diol amines ${ }^{16}$ in the presence of $\mathrm{K}_{2} \mathrm{CO}_{3}$ under microwave irradiation. The yields ranged from $39 \%$ to $73 \%$ and were mostly in the fifties.
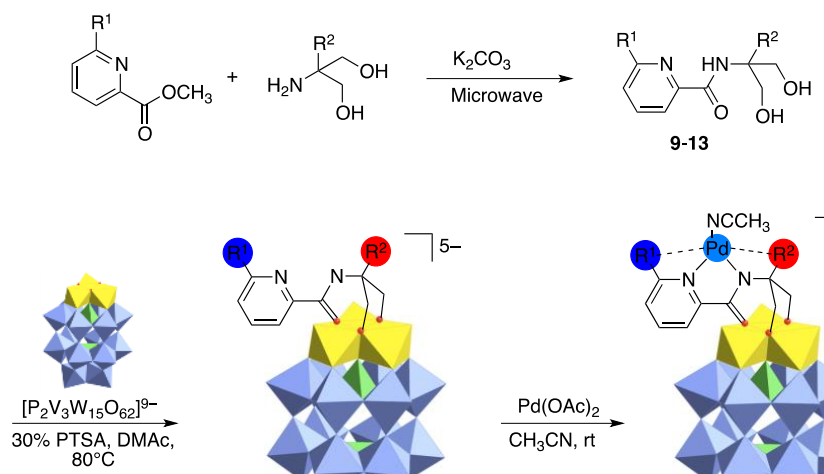

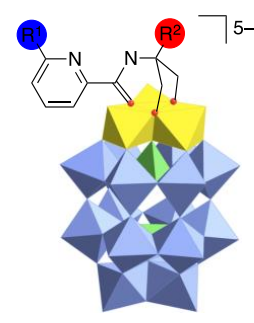

14-18

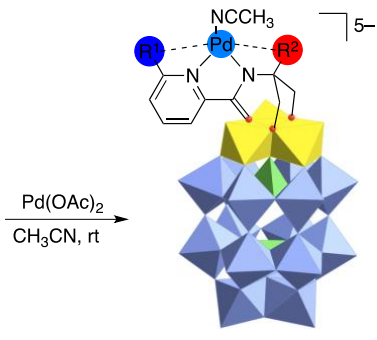

19-21

Scheme 1. preparation of the diol-amide ligands 9-13, the functionalized POMs 14-18 and the palladation yielding POM-Pd hybrids 19-21. The Pd forms an additional bond with either $\mathrm{R}^{1}$ or $\mathrm{R}^{2}$, see Table 1 .

The organohybrid ligands were then prepared following our previously reported method. ${ }^{13}$ In a typical example, Dawson POM (TBA) ${ }_{5} \mathrm{H}_{4}\left[\mathrm{P}_{2} \mathrm{~W}_{15} \mathrm{~V}_{3} \mathrm{O}_{62}\right]$ (1) was reacted with amido-diol 9 and 30 mol \% of para-toluenesulfonic acid (PTSA) in dimethylacetamide (DMAc) under microwave heating at $80{ }^{\circ} \mathrm{C}$ for $35 \mathrm{~min}$ (table 1, entry 1). POM 14 was isolated in $82 \%$ yield after precipitation with $\mathrm{Et}_{2} \mathrm{O}$ and centrifugation. 

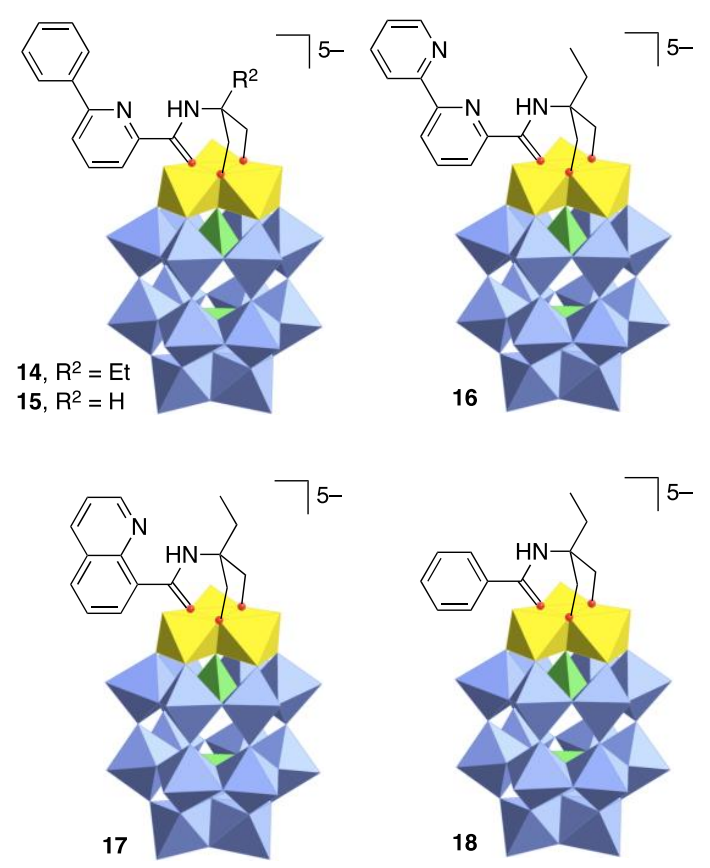

Figure 4. New structures examined in this article.

The reaction worked well with all the new diolamides (86-93\%, see Table 1), and the ligand grafting to 1, leading to 14-18 was confirmed by IR, ESI-MS and multinuclear NMR methods.

Table 1. Preparations of diol amides 9-13, hybrid POMs 14-18 and POM-Palladacycles 19-20.

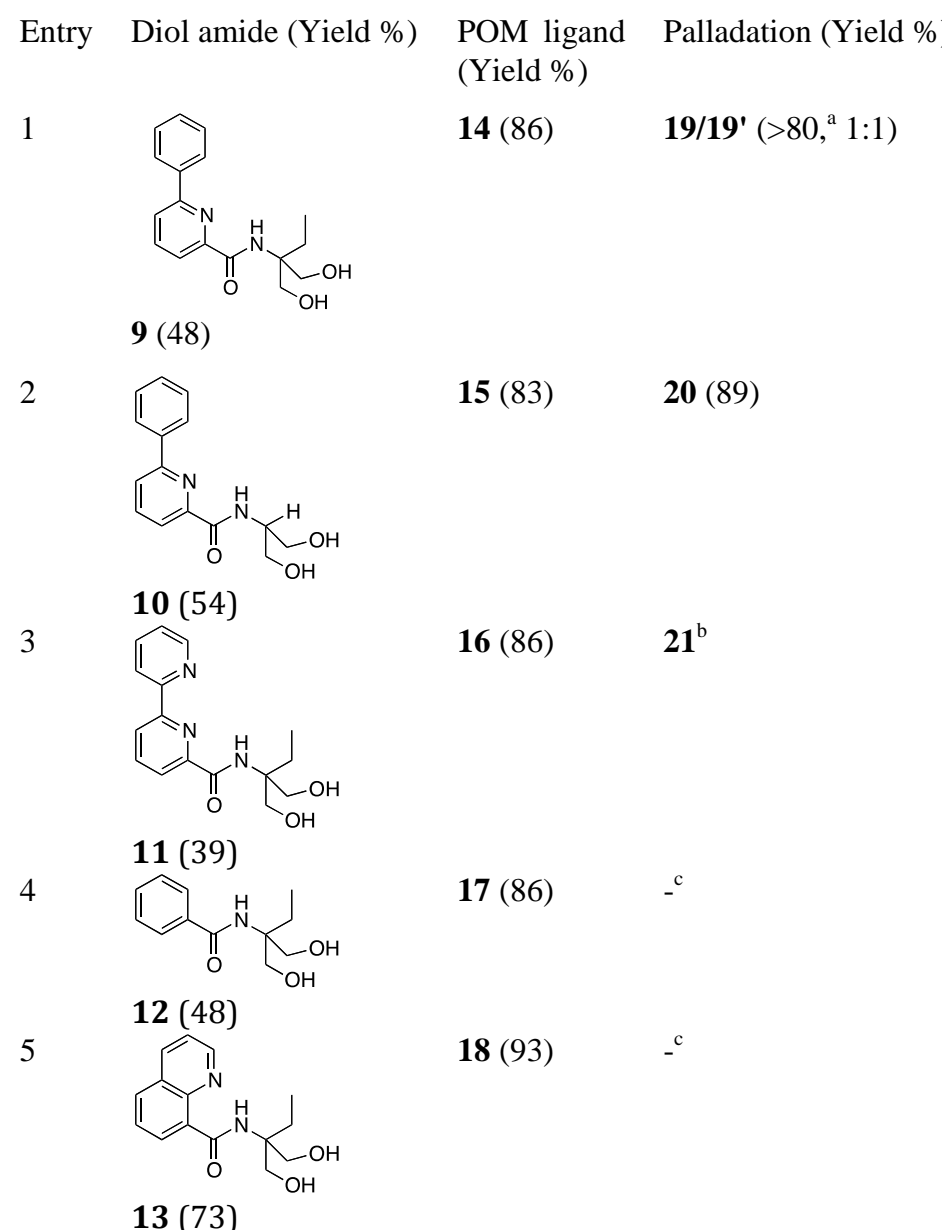

$13(73)$

${ }^{\mathrm{a}} \mathrm{NMR}$ yield; ${ }^{\mathrm{b}}$ only coordination to $\mathrm{Pd}(\mathrm{OAc})_{2}$ was observed; ${ }^{\mathrm{b}}$ no reaction took place (S. M. recovered). 
The organoPOMs were obtained as TBA salts with varying amounts of dimethylammonium cations, as determined by NMR and elemental analysis.

\subsection{Palladation of $\mathbf{1 4 - 1 8}$}

POMs 14-15 were submitted to the palladation conditions. A solution of the POM ligand was reacted with one equivalent $\mathrm{Pd}(\mathrm{OAc})_{2}$ at $\mathrm{rt}$ in acetonitrile. This gave a clear solution in less than 5 minutes. ${ }^{15}$

For substrate 14, there is a competition between the $\mathrm{C}-\mathrm{H}$ insertion at the $\mathrm{sp}^{3}$ carbon of the ethyl group, and that at the $\mathrm{sp}^{2}$ one on the attached phenyl ring. In this case, we observed the formation of both palladacycles 19 and 19 ' in a 1:1 ratio and $>80 \%$ yield, as shown by NMR analysis (Table 1, entry 1 and Scheme 2 ). When the ethyl was replaced with a hydrogen atom, the competition disappeared and the $\mathrm{C}-\mathrm{H}$ insertion only took place at the ortho phenyl substituent to yield 89\% of isolated 20 (Table 1, entry 2 and Scheme 2). On the other hand, replacement of the phenylpyridine with a bipyridyl blocked the $\mathrm{C}-\mathrm{H}$ insertion at the methyl site (Table 1, entry 3 ). We did not attempt to isolate the palladium complexes in that case.

Finally, no palladation at all took place on the diol-benzamide POM 17, and only starting material was recovered (entry 4). When a quinolylamide was used, as in POM 18, no C-H activation was observed (entry 5).

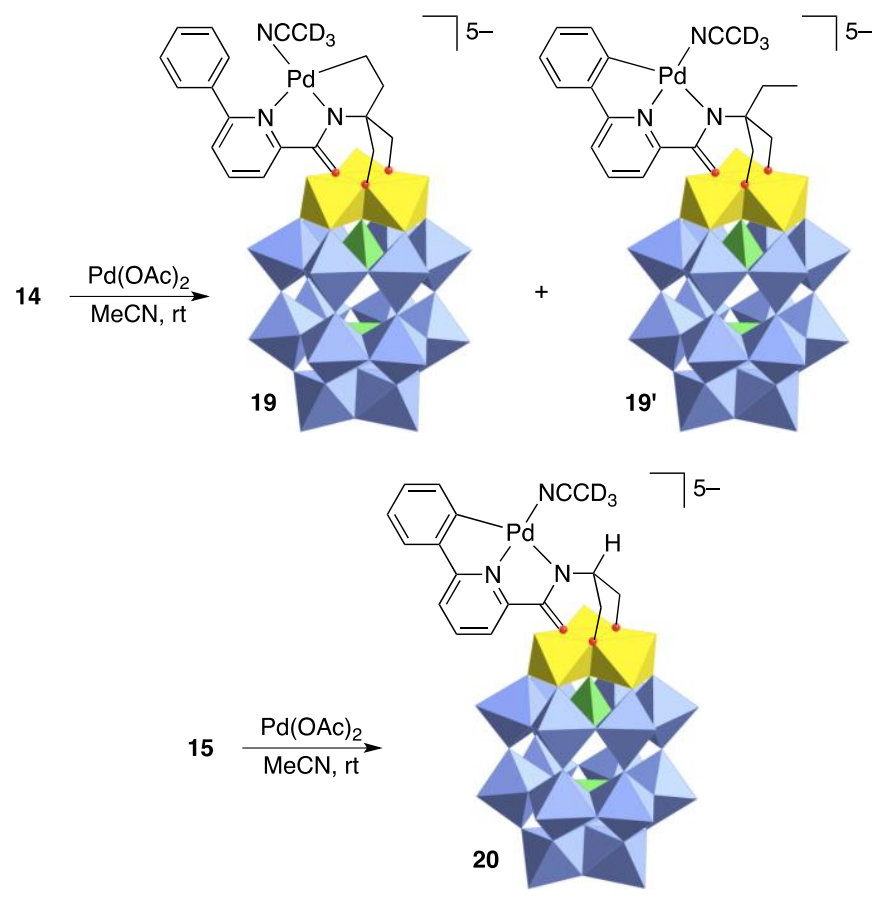

Scheme 2. Competitive formation of palladacycles for the POMs bearing a phenylpyridine-diol-amide

In summary, we can prepare pincer-type hybrids with the Pd atom attached either at the ethyl substituent or at the phenyl in the 6 position of the pyridyl ring, depending on the choice of substituents on the diolamides. However, there is no real preference for one or the other, at least in the simplest case. On the other hand, the palladation requires a pyridyl ring next to the POM-inserted carbonyl. A phenyl group cannot anchor the Pd for the insertion to proceed, and a quinolyl adds too much steric strain for the palladacycle to form.

\subsection{DFT study}

We decided to rationalize this very easy and efficient palladation through $\mathrm{C}-\mathrm{H}$ activation with the use of DFT. In particular we wished to confirm the role of the POM.

The first system treated by DFT was the monopyridine POM vanadate $\mathbf{2}$ with the palladium complexed by one molecule of acetonitrile. We chose acetate as the base to match the experimental conditions (Figure 5).

Two minima were found before the $\mathrm{C}-\mathrm{H}$ activation. One involves the acetate directly coordinated to the palladium center and one has an agostic interaction between the palladium and one $\mathrm{C}-\mathrm{H}$ bond of the ethyl chain $(\mathrm{Pd}-\mathrm{H}$ distance of $1.912 \AA$ ). The agostic interaction is disfavored by only $5.24 \mathrm{kcal} / \mathrm{mol}$. The transition state yielding 2 was found to be $18.54 \mathrm{kcal} / \mathrm{mol}$. This is compatible with the experimental outcome (easy insertion into the $\mathrm{C}-\mathrm{H}$ bond). 


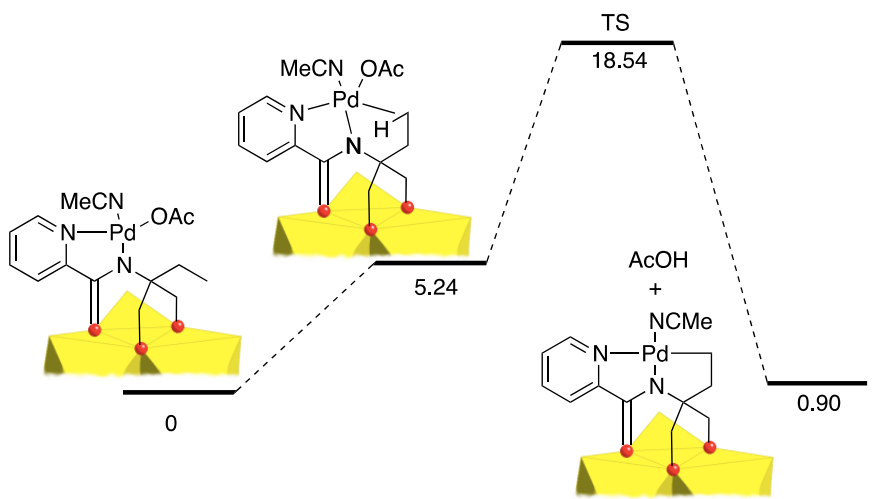

Figure 5. Modeling of the palladation leading to 2. Calculations carried out at the BP86/SV(P) level, energies are in $\mathrm{kcal} / \mathrm{mol}$.

When the carbonyl was reduced (use of a theoretical structure featuring an inserted hemi-aminal, Figure 6), thus breaking the conjugation between the organic part and the inorganic framework, the barrier was found even higher at $41.69 \mathrm{kcal} / \mathrm{mol}$.
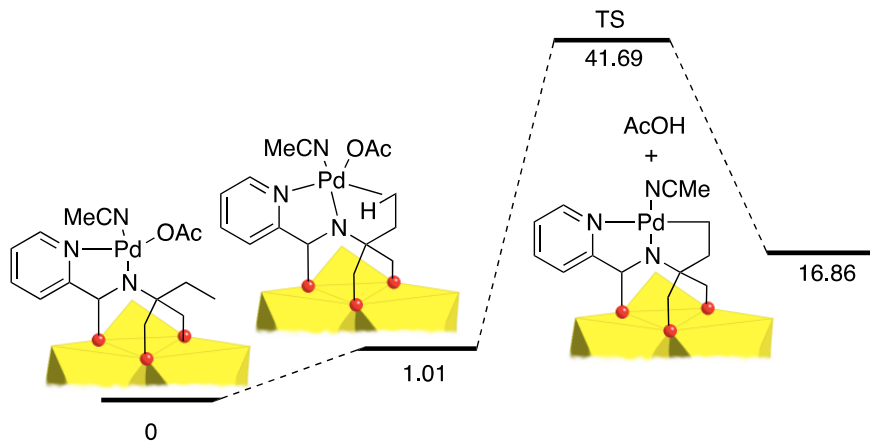

Figure 6. Modeling of the palladation of a hypothetical hemi-aminal POM hybrid. Calculations carried out at the BP86/SV(P) level, energies are in $\mathrm{kcal} / \mathrm{mol}$.

We can conclude that the POM was able to activate the palladium $\mathrm{C}-\mathrm{H}$ insertion step. The strong electronwithdrawing effect of the POM framework is likely transmitted to the palladium center via the inserted conjugated carbonyl, thus making it more electrophilic. As a consequence, the agostic interaction and/or the deprotonation with the acetate are favored, leading to the insertion.

When a bipyridine ligand was installed on the POM (palladation of 16, Figure 7), the palladium was coordinated by the amide nitrogen and the two nitrogen of the bipyridyl moiety. An agostic complex was also found in that case, but much higher in energy $(11.66 \mathrm{kcal} / \mathrm{mol} v s .5 .24 \mathrm{kcal} / \mathrm{mol})$. And the corresponding transition state was also higher $(29.49 \mathrm{kcal} / \mathrm{mol} v s .18 .54 \mathrm{kcal} / \mathrm{mol})$, making the insertion less favorable. This matched the experimental observations (Table 1, entry 3).

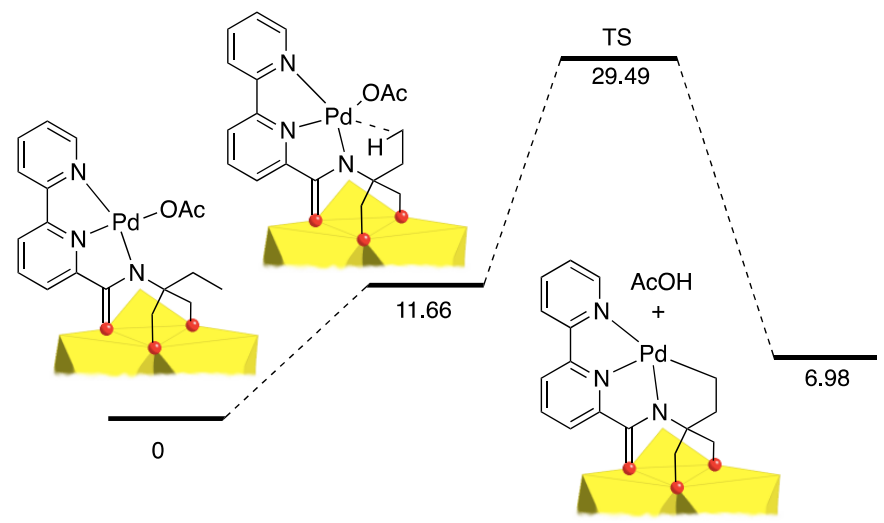

Figure 7. Modeling of the palladation from 16. Calculations carried out at the BP86/SV(P) level, energies are in $\mathrm{kcal} / \mathrm{mol}$.

Models (A) and (C) were used in order to support the influence of the polyoxometalate on the $\mathrm{C}-\mathrm{H}$ activation process (Scheme 3). In model (A), the inorganic part was removed but the organometallic framework was kept 
identical (Scheme 3a). In that case, the barrier for the $\mathrm{C}-\mathrm{H}$ activation to $\mathbf{B}$ was found to be $31.15 \mathrm{kcal} / \mathrm{mol}$. Thus it is clear that the polyoxometalate moiety has a positive effect on the $\mathrm{C}-\mathrm{H}$ activation.

In 2005, Daugulis et al. have published a study in which they demonstrate that palladium complexes similar to the ones used here are able to activate $\mathrm{sp}^{3} \mathrm{C}-\mathrm{H}$ bond. ${ }^{17}$ Complex $(\mathbf{C})$ without the gem-diol part is representative of their work (Scheme $3 b$ ). We found an activation barrier at $21.96 \mathrm{kcal} / \mathrm{mol}$, lower than for $\mathbf{A}$. This value is again compatible with the observed experimental facts of the Daugulis group.

a)

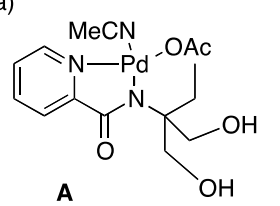

b)<smiles></smiles>

TS $=31.15$<smiles></smiles>

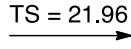

Scheme 3. Modeling of the hypothetical palladation of a) the ligand alone (A) and b) the same ligand without the gem-diol moiety (C). Calculations carried out at the BP86/SV(P) level, energies are in $\mathrm{kcal} / \mathrm{mol}$.

The main differences between complexes $(\mathbf{A})$ and $(\mathbf{C})$ are i) the gem-dihydroxyl group and ii) the presence of acetonitrile as a solvent/ligand. It is possible that acetonitrile disfavors the chelation of the acetate on palladium, which results in an increase of the barrier for the $\mathrm{C}-\mathrm{H}$ activation. It may also be that the gem disubstitution introduces strain. In any case, these negative effects are largely compensated by the polyoxometalate electronic effect.

The electrostatic potentials of palladacycles $\mathbf{2}$ and $\mathbf{B}$ were plotted (Figure 8). In 2, the palladium center is electronrich while in $\mathbf{B}$ it is electron-poor. This shows that the polyoxometalate has a direct influence on the electronic structure of the organometallic moiety because of the conjugation.
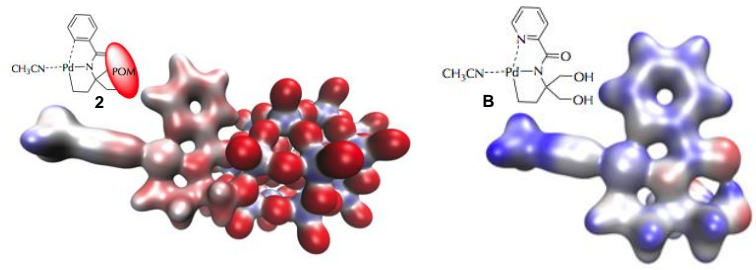

Figure 8. Electrostatic potential mapped on electron density for model system $\mathbf{2}$ and $\mathbf{B}$. Red area represents an excess of electron while blue area indicates electronic depletion.

\subsection{Heck reaction}

We next examined the potential of the palladacycles as catalysts for reactions involving redox steps at Pd. We selected the Mirozoki-Heck coupling of iodobenzene and styrene as a benchmark reaction. Those reactions generally require two open sites on palladium to proceed. However, it has been suggested that some single-site Pd(II) systems might proceed via a Pd(IV) species, ${ }^{18}$ which the POM might stabilize.

In a first experiment, iodobenzene ( 1 equiv.) and styrene (2 equiv.) were mixed in the presence of $\mathrm{Na}_{2} \mathrm{CO}_{3}(1.2$ equiv.) and palladacycle $2(1 \mathrm{~mol} \%)$ in acetonitrile at $80{ }^{\circ} \mathrm{C}$. An encouraging $28 \%$ yield of stilbene was obtained after $20 \mathrm{~h}$ (Table 2, entry 1). When the coordinating solvent $\mathrm{CH}_{3} \mathrm{CN}$ was replaced by DMSO or DMF, the yields improved to 75 and $87 \%$ (entries 2-3). The use of an organic base such as $\mathrm{NEt}_{3}$ did not affect significantly the yield in stilbene (entry 4). Finally, microwave heating was extremely detrimental (entries 5-6).

With the optimized conditions of entry 3 in hands, we probed the catalytic activity of other hybrid POM palladacycles. Ortho substituents (electron donating or electron withdrawing) on the pyridyl moiety did not affect the catalysis. Stilbene was always isolated in good yields (entries 7-9). The aryl-palladium POM species 8 and 20 also catalyzed the reaction (respectively 82 and $78 \%$ yield, entries 10-11). However, in all cases the reaction turned black after a few hours, raising questions on the exact nature of the catalytic species. To answer the question of stability of our palladacycles in these reaction conditions, we turned our attention to the possible recycling of the catalysts. 
We tried to recover the catalysts by precipitation in $\mathrm{Et}_{2} \mathrm{O}$. No matter which $\mathrm{POM}$ we tried to recover, the only recovered solid material was a dark powder, which was not the POM. The degradation of the POM catalyst into a black material suggests the formation of palladium nanoparticles that might well be the true catalyst. Palladium pincer complexes are considered to be precursors of palladium nanoparticles. ${ }^{19}$ In our system, the basic and thermal conditions required to perform the reaction are likely responsible of the degradation of the POM, releasing the palladium for the nanoparticle formation.

Table 2. POM-Pd hybrid-catalyzed Heck reaction

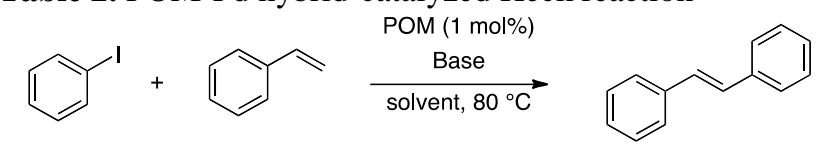

\begin{tabular}{|c|c|c|c|c|c|}
\hline Entry & POM & solvent & base & time $(\mathrm{h})$ & yield (\%) \\
\hline 1 & 2 & $\mathrm{CH}_{3} \mathrm{CN}$ & $\mathrm{Na}_{2} \mathrm{CO}_{3}$ & 20 & 28 \\
\hline 2 & 2 & DMSO & $\mathrm{Na}_{2} \mathrm{CO}_{3}$ & 20 & 75 \\
\hline 3 & 2 & DMF & $\mathrm{Na}_{2} \mathrm{CO}_{3}$ & 20 & 87 \\
\hline 4 & 2 & DMF & $\mathrm{NEt}_{3}$ & 20 & 84 \\
\hline 5 & 2 & DMF & $\mathrm{Na}_{2} \mathrm{CO}_{3}$ & $1^{\mathrm{a}}$ & 37 \\
\hline 6 & 2 & DMF & $\mathrm{NEt}_{3}$ & $1^{\mathrm{a}}$ & 42 \\
\hline 7 & 3 & DMF & $\mathrm{Na}_{2} \mathrm{CO}_{3}$ & 20 & 83 \\
\hline 8 & 5 & DMF & $\mathrm{Na}_{2} \mathrm{CO}_{3}$ & 20 & 75 \\
\hline 9 & 6 & $\mathrm{DMF}$ & $\mathrm{Na}_{2} \mathrm{CO}_{3}$ & 20 & 87 \\
\hline 10 & 8 & DMF & $\mathrm{Na}_{2} \mathrm{CO}_{3}$ & 20 & 82 \\
\hline 11 & 20 & DMF & $\mathrm{Na}_{2} \mathrm{CO}_{3}$ & 20 & 78 \\
\hline
\end{tabular}

${ }^{a}$ Microwave irradiation.

\subsection{Conclusion}

The phosphovanadotungstate polyanion $\left[\mathrm{P}_{2} \mathrm{~W}_{15} \mathrm{~V}_{3} \mathrm{O}_{62}\right]^{9-}$ is a powerful support for organic ligands and the resulting hybrids stabilize palladacycles conjugated to the inorganic framework. One can direct the $\mathrm{C}-\mathrm{H}$ insertion upon appropriate choice of the substitution pattern. DFT modeling showed that the strong electron withdrawing effect of the POM transmitted through the conjugated carbonyl was responsible for this easy insertion. The Mizoroki-Heck reaction proceeded toward formation of stilbene in the presence of the palladacycles. However it is likely that the POMs act as Pd-reservoirs for the formation of nanoparticles. Further work will focus on extending the $\mathrm{C}-\mathrm{H}$ insertion to other metals.

\section{Experimental section}

\subsection{Computational Details}

The TURBOMOLE ${ }^{20}$ software was used to perform QM (DFT) calculations using the B-P86 functional, within the framework of the RI-J approximation. ${ }^{21}$ The SV(P) basis set developed by Ahlrichs ${ }^{22}$ was used for geometry optimization. Despite the large size of the Dawson POM, frequency calculations were performed to ascertain the nature of the intermediates. We recently used this level of calculation to study the regioselective activation of organotin-substituted Dawson POMs $\left[\alpha_{1}-\mathrm{P}_{2} \mathrm{~W}_{17} \mathrm{O}_{61} \mathrm{SnR}\right]^{7-}{ }^{23}$ The description of the latter systems correlated well with their observed behaviors and can thus be considered accurate enough for our purpose. Solvent effects induced by acetonitrile (dielectric constant was set to 36.64) were taken into accound by turning on the COSMO implementation. 


\subsection{Materials}

Reagents and chemicals were purchased from commercial sources and used as received. The starting $\mathrm{TBA}_{5} \mathrm{H}_{4}\left[\mathrm{P}_{2} \mathrm{~V}_{3} \mathrm{~W}_{15} \mathrm{O}_{62}\right]$ was prepared as described in the literature ${ }^{24}$ (Anal. calc. for $\mathrm{TBA}_{5.3}\left(\mathrm{Me}_{2} \mathrm{NH}_{2}\right)_{3.7} \mathrm{P}_{2} \mathrm{~V}_{3} \mathrm{~W}_{15} \mathrm{O}_{62}$.DMF.H $\mathrm{H}_{2} \mathrm{O}$ (5344.40 g.mol ${ }^{-1}$ ): C 19,73 H 3.84, N 1.65; found: C 19.74, H 3.83, N 1.65). Unless otherwise noted, reactions were carried out under argon atmosphere with magnetic stirring in redistilled solvents when necessary. 6-phenyl-pyridine-2-carboxylic acid and 2,2'-dipyridyl-6-carboximidic acid methyl ester were prepared as described in the literature. ${ }^{25}$ Compounds 12 and 17 were prepared as described in a previous publication from our laboratory. ${ }^{13}$ Merck $60 \mathrm{~F}_{254}$ silica gel was used for thin-layer chromatography (TLC) and Merck Geduran SI $60 \AA$ silica gel $60(40-63 \mu \mathrm{M})$ was used for flash column chromatography. Melting points were measured on a Stuart Scientific Melting Point SMP3 apparatus in open capillaries. IR spectra were recorded from a Bruker Tensor 27 ATR diamond PIKE spectrophotometer. NMR ${ }^{1} \mathrm{H},{ }^{31} \mathrm{P},{ }^{13} \mathrm{C}$ spectra were recorded at 400,162 , and 100 $\mathrm{MHz}$, respectively, using a Bruker AVANCE 400 spectrometer equipped with a BBFO probe. Some ${ }^{13} \mathrm{C}$ NMR spectra were recorded at $50 \mathrm{MHz}$ using a Bruker AVANCE 200. Chemical shifts are reported in ppm, using, for ${ }^{1} \mathrm{H}$ and ${ }^{13} \mathrm{C}$, solvent residual peak as internal standard references, and for ${ }^{31} \mathrm{P}$ external $\mathrm{H}_{3} \mathrm{PO}_{4}$. Coupling constants $(J)$ are given in Hertz $(\mathrm{Hz})$, multiplicity $(\mathrm{s}=$ singlet, $\mathrm{d}=$ doublet, $\mathrm{t}=$ triplet, $\mathrm{q}=$ quartet, $\mathrm{m}=$ multiplet $)$. Mass spectrometry experiments have been carried out on an electrospray-ion trap instrument (Bruker, Esquire 3000). The $50 \mu \mathrm{mol} \cdot \mathrm{L}^{-1}$ solutions of POMs were infused using a syringe pump $\left(160 \mu \mathrm{L} \cdot \mathrm{h}^{-1}\right)$. The negative ion mode was used with capillary high voltage $3500 \mathrm{~V}$. The orifice/skimmer voltage difference was set to $45 \mathrm{~V}$ to avoid decomposition of the POMs. The low-mass-cutoff (LMCO) of the ion trap was set to $80 \mathrm{Th}$. Elemental analyses were carried out by ICSN (CNRS, Gif, France).

\subsection{Preparation of the diolamides}

\subsection{1. diolamide 9}

Methyl chloroformate $(116 \mu \mathrm{L}, 1.5 \mathrm{mmol}, 1$ equiv.) was slowly added to a solution of 6-phenyl-pyridine-2carboxylic acid (300 mg, $1.5 \mathrm{mmol}, 1$ equiv.) and $\mathrm{Et}_{3} \mathrm{~N}\left(230 \mu \mathrm{L}, 1.7 \mathrm{mmol}, 1.13\right.$ equiv.) in $\mathrm{THF}(30 \mathrm{~mL})$ at $0{ }^{\circ} \mathrm{C}$ and the resulting mixture was stirred in an ice bath for $30 \mathrm{~min}$. Then, the white precipitate of triethylammonium chloride was removed by filtration. A clear solution of the mixed anhydride was thus obtained and was added to a solution of 2amino-2-ethylpropane-1,3-diol (178 mg, $1.5 \mathrm{mmol}, 1$ equiv.) and $\mathrm{Et}_{3} \mathrm{~N}$ (230 $\mu \mathrm{L}, 1.7 \mathrm{mmol}, 1.13$ equiv.) in THF. The reaction mixture was stirred overnight, and then concentrated. The crude material was purified by column chromatography (petroleum ether/EtOAc: 50/50) to afford the diol-amide 9 as a white solid (216 $\mathrm{mg}, 0.72 \mathrm{mmol}, 48 \%$ yield). m.p. $79.9^{\circ} \mathrm{C}$. IR: $v=3341,2930,1658,1529,1447,1052,753 \mathrm{~cm}^{-1} .{ }^{1} \mathrm{H} \mathrm{NMR}\left(400 \mathrm{MHz}, \mathrm{CDCl}_{3}\right): \delta=8.75(\mathrm{br}$ s, $1 \mathrm{H}, \mathrm{NH}), 8.12(\mathrm{dd}, J=7.4,1.3 \mathrm{~Hz}, 1 \mathrm{H}$, arom.), 8.01-7.98 (m, 2H, arom.), 7.95-7.88 (m, 2H, arom.), 7.54-7.45 (m, $3 \mathrm{H}$, arom.), 4.07 (br s, 2H, OH), 4.01 (A of $\mathrm{AB}, J=11.7,2 \mathrm{H}, \mathrm{CHHOH}), 3.74(\mathrm{~B}$ of $\mathrm{AB}, J=11.7 \mathrm{~Hz}, 2 \mathrm{H}, \mathrm{CH} H \mathrm{OH}$ ), $1.82\left(\mathrm{q}, J=7.6 \mathrm{~Hz}, 2 \mathrm{H}, \mathrm{CH}_{2} \mathrm{Me}\right), 1.05\left(\mathrm{t}, J=7.6 \mathrm{~Hz}, 3 \mathrm{H}, \mathrm{CH}_{2} \mathrm{Me}\right) .{ }^{13} \mathrm{C} \mathrm{NMR}\left(100 \mathrm{MHz}, \mathrm{CDCl}_{3}\right): \delta=165.4(\mathrm{C}=\mathrm{O})$, 156.0 (C arom.), 149.6 (C arom.), 138.6 (CH arom.), 138.2 (C arom.), 129.7 (CH arom.) 129.1 (CH arom.), 126.9 (CH arom.), $123.3\left(\mathrm{CH}\right.$ arom.), $120.6\left(\mathrm{CH}\right.$ arom.), $65.9\left(\mathrm{CH}_{2} \mathrm{OH}\right), 61.3(\mathrm{CNH}), 26.7\left(\mathrm{CH}_{2} \mathrm{Me}\right), 7.7\left(\mathrm{CH}_{2} \mathrm{Me}\right)$. HRMS calc. for $\mathrm{C}_{17} \mathrm{H}_{20} \mathrm{~N}_{2} \mathrm{O}_{3} \mathrm{Na}$ : 323.1366; found: 323.1356 .

\subsection{2. diolamide 10}

Methyl chloroformate $(116 \mu \mathrm{L}, 1.5 \mathrm{mmol}, 1$ equiv.) was slowly added to a solution of 6-phenyl-pyridine-2carboxylic acid (300 mg, $1.5 \mathrm{mmol}, 1$ equiv.) and $\mathrm{Et}_{3} \mathrm{~N}\left(230 \mu \mathrm{L}, 1.7 \mathrm{mmol}, 1.13\right.$ equiv.) in $\mathrm{THF}(30 \mathrm{~mL})$ at $0{ }^{\circ} \mathrm{C}$ and the mixture was stirred in an ice bath for $30 \mathrm{~min}$. The white precipitate of triethylammonium chloride was removed by filtration. A clear solution of the mixed anhydride was thus obtained and was added to a solution of 2-amino-propane1,3-diol (137 mg, $1.5 \mathrm{mmol}, 1$ equiv.) and $\mathrm{Et}_{3} \mathrm{~N}(230 \mu \mathrm{L}, 1.7 \mathrm{mmol}, 1.13$ equiv.) in THF. The reaction mixture was stirred overnight, and then concentrated. The crude material was purified by column chromatography (petroleum ether/EtOAc: 50/50) to afford the diol-amide $\mathbf{1 0}$ as a white solid $\left(220 \mathrm{mg}, 0.81 \mathrm{mmol}, 54 \%\right.$ yield). m.p. $118.3{ }^{\circ} \mathrm{C}$. IR: v $=3367,2946,1656,1526,1446,1047,753 \mathrm{~cm}^{-1} .{ }^{1} \mathrm{H}$ NMR $\left(400 \mathrm{MHz}, \mathrm{CDCl}_{3}\right): \delta=8.79(\mathrm{br} \mathrm{s}, 1 \mathrm{H}, \mathrm{NH}), 8.10(\mathrm{dd}, J=$ 7.3, 1.5 Hz, 1H, arom.), 8.01-7.98 (m, 2H, arom.), 7.90-7.83 (m, 2H, arom.), 7.52-7.42 (m, 3H, arom.), 4.18-4.13 (m, $1 \mathrm{H}, \mathrm{CHNH}), 3.99-3.91(\mathrm{~m}, 4 \mathrm{H}, \mathrm{CHHOH}$ and $\mathrm{OH}), 3.15$ (br s, $2 \mathrm{H}, \mathrm{CHHOH}) .{ }^{13} \mathrm{C} \mathrm{NMR}\left(100 \mathrm{MHz}, \mathrm{CDCl}_{3}\right): \delta=165.4$ (C=O), 156.2 (C arom.), 149.4 (C arom.), 138.4 ( $\mathrm{CH}$ arom.), 138.2 (C arom.), 129.7 ( $\mathrm{CH}$ arom.) 129.0 (CH arom.), 127.1 ( $\mathrm{CH}$ arom.), 123.3 ( $\mathrm{CH}$ arom.), 120.8 ( $\mathrm{CH}$ arom.), $63.5\left(\mathrm{CH}_{2} \mathrm{OH}\right), 53.1$ (CHNH). HRMS calc. for $\mathrm{C}_{15} \mathrm{H}_{16} \mathrm{~N}_{2} \mathrm{O}_{3} \mathrm{Na}$ : 295.1058; found: 295.1070.

\subsection{3. diolamide 11}

2,2'-dipyridyl-6-carboximidic acid methyl ester ( $108 \mathrm{mg}, 0.51 \mathrm{mmol}, 1$ equiv.) was added to a solution of 2-amino2-ethylpropane-1,3-diol (61 mg, $0.51 \mathrm{mmol}, 1$ equiv.) in chlorobenzene $(5 \mathrm{~mL})$ at room temperature. The reaction mixture was refluxed for 3 days, and then concentrated. The crude material was purified by column chromatography (petroleum ether/EtOAc: 50/50) to afford the diol-amide $\mathbf{1 1}$ as a pale yellow oil (63 $\mathrm{mg}, 0.19 \mathrm{mmol}, 39 \%$ yield). IR: $v$ $=3345,3065,2955,1658,1529,1437,1042,902,760 \mathrm{~cm}^{-1} .{ }^{1} \mathrm{H}$ NMR $\left(400 \mathrm{MHz}, \mathrm{CDCl}_{3}\right) \delta=8.72(\mathrm{~s}, 1 \mathrm{H}, \mathrm{NH}), 8.66-$ 8.61 (m, 1H, arom.), 8.47 (dd, $J=7.9,0.8 \mathrm{~Hz}, 1 \mathrm{H}$, arom.), 8.24 (d, $J=7.9 \mathrm{~Hz}, 1 \mathrm{H}$, arom.), 8.07 (dd, $J=7.6,0.8 \mathrm{~Hz}$, $1 \mathrm{H}$, arom.), 7.89 (t, $J=7.8 \mathrm{~Hz}, 1 \mathrm{H}$, arom.), 7.78 (td, $J=7.8,1.7 \mathrm{~Hz}, 1 \mathrm{H}$, arom.), 7.29 (ddd, $J=7.6,4.8,0.8 \mathrm{~Hz}, 1 \mathrm{H}$, arom.), $4.53(\mathrm{~s}, 2 \mathrm{H}, \mathrm{OH}), 3.96(\mathrm{~A}$ of $\mathrm{AB}, J=11.7 \mathrm{~Hz}, 2 \mathrm{H}, \mathrm{CHHOH}), 3.73(\mathrm{~B}$ of $\mathrm{AB}, J=11.7 \mathrm{~Hz}, 2 \mathrm{H}, \mathrm{CH} H \mathrm{OH}), 1.81$ $\left(\mathrm{q}, J=7.5 \mathrm{~Hz}, 2 \mathrm{H}, \mathrm{CH}_{2} \mathrm{Me}\right), 0.97\left(\mathrm{t}, J=7.5 \mathrm{~Hz}, 3 \mathrm{H}, \mathrm{CH}_{2} \mathrm{Me}\right) .{ }^{13} \mathrm{C}$ NMR $\left(100 \mathrm{MHz}, \mathrm{CDCl}_{3}\right): \delta=165.0(\mathrm{C}=\mathrm{O}), 154.9$ 
(C arom.), 154.7 (C arom.), 149.5 (C arom.), 149.2 (CH arom.), 138.7 (CH arom.), 137.3 (CH arom.), 124.4 (CH arom.), 123.9 ( $\mathrm{CH}$ arom.), 122.1 ( $\mathrm{CH}$ arom.), 121.1 ( $\mathrm{CH}$ arom.), $65.8\left(\mathrm{CH}_{2} \mathrm{OH}\right), 61.3(\mathrm{CNH}), 25.9\left(\mathrm{CH}_{2} \mathrm{Me}\right), 7.8$ $\left(\mathrm{CH}_{2} \mathrm{Me}\right)$. HRMS calc. for $\mathrm{C}_{16} \mathrm{H}_{19} \mathrm{~N}_{3} \mathrm{O}_{3} \mathrm{Na}$ : 324.1324; found: 324.1329 .

\subsection{4. diolamide 13}

Ethyl quinoline-8-carboxylate (200 mg, $1 \mathrm{mmol}, 1$ equiv.), 2-amino-2-ethylpropane-1,3-diol (131 mg, $1.1 \mathrm{mmol}$, 1.1 equiv.) and $\mathrm{K}_{2} \mathrm{CO}_{3}(151 \mathrm{mg}, 1.1 \mathrm{mmol}, 1.1$ equiv.). were dissolved in DMSO ( $3 \mathrm{~mL})$ in a sealed microwave vial containing a stir bar. The mixture was heated under MW to $100{ }^{\circ} \mathrm{C}$ for $45 \mathrm{~min}$. The suspension was filtered and the solvent was evaporated under reduced pressure (water bath $90{ }^{\circ} \mathrm{C}$ ). The crude material was purified by column chromatography (DCM/MeOH: 90/10) to afford the diol-amide 13 as an orange oil (200 $\mathrm{mg}, 0.73 \mathrm{mmol}, 73 \%$ yield). IR: $v=3378,2968,1639,1572,1054,796 \mathrm{~cm}^{-1} .{ }^{1} \mathrm{H} \mathrm{NMR}\left(400 \mathrm{MHz}, \mathrm{CDCl}_{3}\right): \delta=11.67$ (br s, $\left.1 \mathrm{H}, \mathrm{NH}\right), 8.92(\mathrm{dd}, J=$ 4.3, $1.9 \mathrm{~Hz}, 1 \mathrm{H}$, arom.), 8.80 (dd, $J=7.9,1.9 \mathrm{~Hz}, 1 \mathrm{H}$, arom.), 8.31 (dd, $J=8.3,1.4 \mathrm{~Hz}, 1 \mathrm{H}$, arom.), 7.99 (dd, $J=8.3$, $1.4 \mathrm{~Hz}, 1 \mathrm{H}$, arom.), 7.69 (t, $J=8.3 \mathrm{~Hz}, 1 \mathrm{H}$, arom.), 7.52 (dd, $J=7.9,4.3 \mathrm{~Hz}, 1 \mathrm{H}$, arom.), 4.48 (br s, A of AB, 2H, $\mathrm{CHHOH}), 4.09(\mathrm{~d}, J=12.2 \mathrm{~Hz}, 2 \mathrm{H}, \mathrm{OH}), 3.77(\mathrm{~B}$ of AB, $J=12.2 \mathrm{~Hz}, 2 \mathrm{H}, \mathrm{CH} H \mathrm{OH}) .1 .86\left(\mathrm{q}, J=7.6 \mathrm{~Hz}, 2 \mathrm{H}, \mathrm{CH} \mathrm{H}_{2} \mathrm{Me}\right)$, $1.13\left(\mathrm{t}, J=7.6 \mathrm{~Hz}, 3 \mathrm{H}, \mathrm{CH}_{2} \mathrm{Me}\right) .{ }^{13} \mathrm{C} \mathrm{NMR}\left(100 \mathrm{MHz}_{\mathrm{CDCl}}\right): \delta=167.1(\mathrm{C}=\mathrm{O}), 149.4(\mathrm{CH}$ arom. $), 145.6(\mathrm{C}$ arom. $)$, 138.1 (CH arom.), 133.9 (CH arom.), 132.4 ( $\mathrm{CH}$ arom.), 128.9 (C arom.), 128.9 (C arom.), 126.7 ( $\mathrm{CH}$ arom.), 121.2 (CH arom.), 66.1 $\left(\mathrm{CH}_{2} \mathrm{OH}\right), 62.3(\mathrm{CNH}), 27.4\left(\mathrm{CH}_{2} \mathrm{Me}\right), 7.8\left(\mathrm{CH}_{2} \mathrm{Me}\right)$. HRMS calc. for $\mathrm{C}_{15} \mathrm{H}_{18} \mathrm{~N}_{2} \mathrm{O}_{3} \mathrm{Na}$ : 297.1210; found: 297.1229.

\subsection{GP1: preparation of the hybrid polyoxometalate ligands}

TBA $_{5.7} \mathrm{H}_{3.3}\left[\mathrm{P}_{2} \mathrm{~V}_{3} \mathrm{~W}_{15} \mathrm{O}_{62}\right]$ (300 mg, $0.058 \mathrm{mmol}, 1$ equiv.), PTSA (2.2 mg, $0.012 \mathrm{mmol}, 0.2$ equiv.) and the diolamide $(0.069 \mathrm{mmol}, 1.2$ equiv. $)$ were dissolved in DMA $(0.6 \mathrm{~mL})$ in a sealed microwave vial containing a stir bar. The reaction was heated to $80^{\circ} \mathrm{C}$ under $\mu \mathrm{W}$ for $35 \mathrm{~min}$ (with stirring). The reaction mixture was then quickly transferred to a round-bottom flask with a minimal amount of acetonitrile. The combined solvents were removed in vacuo. The crude yellow oil was dissolved with a minimal amount of acetonitrile and then transferred to a round-bottom $50 \mathrm{~mL}$ glass centrifuge tube and $\mathrm{Et}_{2} \mathrm{O}(30 \mathrm{~mL})$ was added to precipitate the product as a yellow powder (sometimes a yellow-brown paste also formed which transformed into the same powder upon trituration with a spatula). After centrifugation, the colorless supernatant was removed from the tube, and the powder was air-dried. It was then redissolved in a minimal amount of acetonitrile (less than $0.5 \mathrm{~mL}$ is required), precipitated with ethanol $(30 \mathrm{~mL})$, triturated if needed, and centrifugated again. The orange supernatant was discarded and the remaining solid was triturated in diethyl ether. The ether was removed by centrifugation. The resulting powder was then finely dried under vacuum to afford the pure functionalized POMs.

\subsubsection{POM ligand 14}

Following GP1 from the diol-amide $9(20.7 \mathrm{mg}, 0.069 \mathrm{mmol})$. POM 14 was isolated as a yellow powder (264 mg, 0.049 mmol, 86\% yield). IR: $v=2961,2874,1623,1580,1483,1482,1380,1085,951,900,805,731 \mathrm{~cm}^{-1} .{ }^{1} \mathrm{H} \mathrm{NMR}$ $\left(400 \mathrm{MHz}, \mathrm{CD}_{3} \mathrm{CN}\right): \delta=10.52$ (br s, $\left.1 \mathrm{H}, \mathrm{NH}\right), 8.76(\mathrm{~d}, J=6.4,2.1 \mathrm{~Hz}, 1 \mathrm{H}$, arom.), 8.17-8.14 (m, 2H, arom.), 7.587.52 (m, 3H, arom.), 6.93 (br s, $0.4 \mathrm{H}, \mathrm{Me}_{2} \mathrm{NH}_{2}$ ), 5.68 (A of AB, $\left.J=12.8 \mathrm{~Hz}, 2 \mathrm{H}, \mathrm{CHHOV}\right), 5.55$ (B of AB, $J=12.8$ $\mathrm{Hz}, 2 \mathrm{H}, \mathrm{CHHOV}), 3.19-3.15$ (m, 38.4H, N( $\left.\left.\mathrm{CH}_{2} \mathrm{CH}_{2} \mathrm{CH}_{2} \mathrm{Me}\right)_{4}\right), 3.02$ (br s, $\left.1.2 \mathrm{H}, \mathrm{Me}_{2} \mathrm{NH}_{2}\right), 1.99$ (q, $J=7.7 \mathrm{~Hz}, 2 \mathrm{H}$, $\left.\mathrm{CH}_{2} \mathrm{Me}\right), 1.69-1.61\left(\mathrm{~m}, 38.4 \mathrm{H}, \mathrm{N}\left(\mathrm{CH}_{2} \mathrm{CH}_{2} \mathrm{CH}_{2} \mathrm{Me}\right)_{4}\right), 1.47-1.38\left(\mathrm{~m}, 38.4 \mathrm{H}, \mathrm{N}\left(\mathrm{CH}_{2} \mathrm{CH}_{2} \mathrm{CH}_{2} \mathrm{Me}\right)_{4}\right), 1.19(\mathrm{t}, J=7.7 \mathrm{~Hz}$ $\left.\mathrm{CH}_{2} \mathrm{Me}\right)$, 1.01-0.97 (m, 57.6H, N $\left.\left(\mathrm{CH}_{2} \mathrm{CH}_{2} \mathrm{CH}_{2} \mathrm{Me}\right)_{4}\right) .{ }^{13} \mathrm{C} \mathrm{NMR}\left(100 \mathrm{MHz}, \mathrm{CD}_{3} \mathrm{CN}\right): \delta=179.1(\mathrm{C}=\mathrm{O}), 158.1(\mathrm{C}$ arom.), 145.9 (C arom.), 140.7 ( $\mathrm{CH}$ arom.), 138.1 (C arom.), 131.2 (CH arom.) 130.0 (CH arom.), 128.2 (CH arom.), 127.6 (CH arom.), 127.1 ( $\mathrm{CH}$ arom.), $89.9\left(\mathrm{CH}_{2} \mathrm{OV}\right), 64.3(\mathrm{CNH}), 59.3\left(\mathrm{~N}\left(\mathrm{CH}_{2} \mathrm{CH}_{2} \mathrm{CH}_{2} \mathrm{Me}\right)_{4}\right), 36.5\left(\mathrm{Me}_{2} \mathrm{NH}_{2}\right), 29.1$

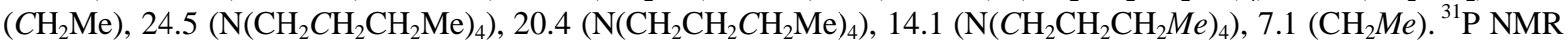
$\left(162 \mathrm{MHz}, \mathrm{CD}_{3} \mathrm{CN}\right) \delta=-5.71(\mathrm{~s}, 1 \mathrm{P}),-11.74(\mathrm{~s}, 1 \mathrm{P})$. Anal. calc. for $\mathrm{TBA}_{4,8}\left(\mathrm{Me}_{2} \mathrm{NH}_{2}\right)_{0.2} \mathrm{C}_{17} \mathrm{H}_{18} \mathrm{~N}_{2} \mathrm{O}_{62} \mathrm{P}_{2} \mathrm{~V}_{3} \mathrm{~W}_{15}(5387.88$ g.mol ${ }^{-1}$ ): C 20.99, H 3.59, N 1.81; found: C 21.23, H 3.65, N 1.83 .

\subsubsection{POM ligand 15}

Following GP1 from the diol-amide $10(18.7 \mathrm{mg}, 0.069 \mathrm{mmol})$. POM 15 was isolated as a yellow powder (253 mg, 0.048 mmol, $83 \%$ yield). IR: $v=2962,2874,1623,1582,1484,1380,1086,954,900,804,760,731 \mathrm{~cm}^{-1} .{ }^{1} \mathrm{H} \mathrm{NMR}$ (400 MHz, $\left.\mathrm{CD}_{3} \mathrm{CN}\right): \delta=11.39(\mathrm{~d}, J=6.7 \mathrm{~Hz}, 1 \mathrm{H}, \mathrm{NH}), 8.71(\mathrm{dd}, J=6.4,2.2 \mathrm{~Hz}, 1 \mathrm{H}$, arom.), 8.27-8.25 (m, 4H, arom.), 7.59 (t, $J=7.7 \mathrm{~Hz}, 2 \mathrm{H}$, arom.), 7.52 (dd, $J=7.7,1.2 \mathrm{~Hz}, 1 \mathrm{H}$, arom.), 6.79 (br s, 1.2H, $\mathrm{Me}_{2} \mathrm{NH}_{2}$ ), 5.98 (A of $\mathrm{AB}, J=12.3 \mathrm{~Hz}, 2 \mathrm{H}, \mathrm{CHHOV}), 5.64$ (B of AB, $J=12.3 \mathrm{~Hz}, 2 \mathrm{H}, \mathrm{CH} H \mathrm{OV}$ ), 4.61 (br s, $1 \mathrm{H}, \mathrm{CHNH}), 3.16-3.13$ (m, $\left.32.5 \mathrm{H}, \mathrm{N}\left(\mathrm{CH}_{2} \mathrm{CH}_{2} \mathrm{CH}_{2} \mathrm{Me}\right)_{4}\right), 2.96$ (br s, 3.6H, $\left.\mathrm{Me}_{2} \mathrm{NH}_{2}\right), 1.67-1.61$ (m, 35.2H, N( $\left.\left.\mathrm{CH}_{2} \mathrm{CH}_{2} \mathrm{CH}_{2} \mathrm{Me}\right)_{4}\right), 1.44-1.38(\mathrm{~m}$, $\left.35.2 \mathrm{H}, \mathrm{N}\left(\mathrm{CH}_{2} \mathrm{CH}_{2} \mathrm{CH}_{2} \mathrm{Me}\right)_{4}\right), 1.00-0.98\left(\mathrm{~m}, 52.8 \mathrm{H}, \mathrm{N}\left(\mathrm{CH}_{2} \mathrm{CH}_{2} \mathrm{CH}_{2} \mathrm{Me}\right)_{4}\right) .{ }^{13} \mathrm{C}$ NMR $\left(100 \mathrm{MHz}, \mathrm{CD}_{3} \mathrm{CN}\right): \delta=179.6$ $(\mathrm{C}=\mathrm{O}), 158.4$ (C arom.), 145.8 (C arom.), 140.5 (CH arom.), 138.1 (C arom.), 131.5 (CH arom.), 130.0 (CH arom.), 128.3 (CH arom.), 127.4 ( $\mathrm{CH}$ arom.), 127.3 (CH arom.), $85.7\left(\mathrm{CH}_{2} \mathrm{OV}\right), 59.3\left(\mathrm{~N}\left(\mathrm{CH}_{2} \mathrm{CH}_{2} \mathrm{CH}_{2} \mathrm{Me}\right)_{4}\right), 57.2(\mathrm{CNH}), 36.8$ $\left(\mathrm{Me}_{2} \mathrm{NH}_{2}\right), 24.4\left(\mathrm{~N}\left(\mathrm{CH}_{2} \mathrm{CH}_{2} \mathrm{CH}_{2} \mathrm{Me}\right)_{4}\right), 20.4\left(\mathrm{~N}\left(\mathrm{CH}_{2} \mathrm{CH}_{2} \mathrm{CH}_{2} \mathrm{Me}\right)_{4}\right), 13.9\left(\mathrm{~N}_{(}\left(\mathrm{CH}_{2} \mathrm{CH}_{2} \mathrm{CH}_{2} \mathrm{Me}\right)_{4}\right)$. ${ }^{31} \mathrm{P} \mathrm{NMR}(162 \mathrm{MHz}$, $\left.\mathrm{CD}_{3} \mathrm{CN}\right) \delta=-5.91(\mathrm{~s}, 1 \mathrm{P}),-11.48$ (s, 1P). Anal. calc. for $\mathrm{TBA}_{4,4}\left(\mathrm{Me}_{2} \mathrm{NH}_{2}\right)_{0.6} \mathrm{C}_{15} \mathrm{H}_{14} \mathrm{~N}_{2} \mathrm{O}_{62} \mathrm{P}_{2} \mathrm{~V}_{3} \mathrm{~W}_{15}\left(5281.28\right.$ g.mol $\left.{ }^{-1}\right): \mathrm{C}$ 19.69, H 3.38, N 1.85; found: C 19.76, H 3.44, N 1.91.

\subsubsection{POM ligand 16}

Following GP1from the diol-amide $11(18.7 \mathrm{mg}, 0.069 \mathrm{mmol})$. POM 16was isolated as a yellow powder (256 mg, 0.048 mmol, $86 \%$ yield). IR: $v=2955,2890,1625,1578,1385,1091,951,894,755,732 \mathrm{~cm}^{-1} .{ }^{1} \mathrm{H} \mathrm{NMR}(400 \mathrm{MHz}$, 
$\left.\mathrm{CD}_{3} \mathrm{CN}\right) \delta=8.87$ (d, $J=7.7 \mathrm{~Hz}, 1 \mathrm{H}$, arom.), 8.77 (d, $J=7.8 \mathrm{~Hz}, 1 \mathrm{H}$, arom.), 8.74 (br s, $1 \mathrm{H}$, arom.), $8.54(\mathrm{~d}, J=7.7$ $\mathrm{Hz}, 1 \mathrm{H}$, arom.), 8.27 (t, $J=7.8 \mathrm{~Hz}, 1 \mathrm{H}$, arom.), 8.03 (br s, 1H, arom.), 7.53 (br s, $1 \mathrm{H}$, arom.), 5.66 (A of $\mathrm{AB}, J=12.6$ $\mathrm{Hz}, 2 \mathrm{H}, \mathrm{CHHOH}), 5.52(\mathrm{~B}$ of $\mathrm{AB}, J=12.6 \mathrm{~Hz}, 2 \mathrm{H}, \mathrm{CH} H \mathrm{OH}), 3.19-3.16\left(\mathrm{~m}, 40 \mathrm{H}, \mathrm{N}\left(\mathrm{CH}_{2} \mathrm{CH}_{2} \mathrm{CH}_{2} \mathrm{Me}\right)_{4}\right), 2.02-2.01(\mathrm{~m}$, $\left.2 \mathrm{H}, \mathrm{CH}_{2} \mathrm{Me}\right), 1.65-161\left(\mathrm{~m}, 40 \mathrm{H}, \mathrm{N}\left(\mathrm{CH}_{2} \mathrm{CH}_{2} \mathrm{CH}_{2} \mathrm{Me}\right)_{4}\right), 1.45-1.39\left(\mathrm{~m}, 40 \mathrm{H}, \mathrm{N}\left(\mathrm{CH}_{2} \mathrm{CH}_{2} \mathrm{CH}_{2} \mathrm{Me}\right)_{4}\right), 1.20(\mathrm{t}, J=7.8 \mathrm{~Hz}$, $\left.3 \mathrm{H}, \mathrm{CH}_{2} \mathrm{Me}\right), 0.99-0.96\left(\mathrm{~m}, 60 \mathrm{H}, \mathrm{N}\left(\mathrm{CH}_{2} \mathrm{CH}_{2} \mathrm{CH}_{2} \mathrm{Me}\right)_{4}\right) .{ }^{13} \mathrm{C} \mathrm{NMR}\left(100 \mathrm{MHz}, \mathrm{CD}_{3} \mathrm{CN}\right): \delta=178.9(\mathrm{C}=\mathrm{O}), 156.9(\mathrm{C}$ arom.), 154.4 (C arom.), 153.3 (CH arom.), 145.9 (CH arom.), 140.6 (CH arom.), 138.8 (C arom.), 128.7 (CH arom.) 127.4 ( $\mathrm{CH}$ arom.), 126.2 ( $\mathrm{CH}$ arom.), 122.3 (CH arom.), $\left.89.7\left(\mathrm{CH}_{2} \mathrm{OV}\right), 64.3(\mathrm{CNH}), 59.2\left(\mathrm{~N}_{(} \mathrm{CH}_{2} \mathrm{CH}_{2} \mathrm{CH}_{2} \mathrm{Me}\right)_{4}\right), 29.1$

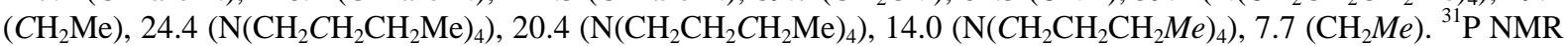
$\left(162 \mathrm{MHz}, \mathrm{CD}_{3} \mathrm{CN}\right) \delta=-5.70(\mathrm{~s}, 1 \mathrm{P}),-11.86$ (s, 1P). Anal. calc. for $\mathrm{TBA}_{5} \mathrm{C}_{16} \mathrm{H}_{17} \mathrm{~N}_{3} \mathrm{O}_{62} \mathrm{P}_{2} \mathrm{~V}_{3} \mathrm{~W}_{15}\left(5428.15\right.$ g.mol $\left.{ }^{-1}\right): \mathrm{C}$ 21.24, H 3.65, N 2.09; found: C 21.06, H 3.62, N 1.98.

\subsubsection{POM ligand 18}

Following GP1 from the diol-amide $13(18.9 \mathrm{mg}, 0.069 \mathrm{mmol})$. POM 18 was isolated as a yellow powder (288 $\mathrm{mg}$, 0.054 mmol, 93\% yield). IR: $v=2964,2871,1661,1599,1483,1087,952,901,811,731 \mathrm{~cm}^{-1} .{ }^{1} \mathrm{H}$ NMR $(400 \mathrm{MHz}$, $\mathrm{d}_{6}$-DMSO): $\delta=14.89$ (br s, $\left.1 \mathrm{H}, \mathrm{NH}\right), 9.34$ (dd, $J=7.5,1.7 \mathrm{~Hz}, 1 \mathrm{H}$, arom.), 9.18 (dd, $J=4.4,1.7 \mathrm{~Hz}, 1 \mathrm{H}$, arom.), 8.82 (dd, $J=8.6,1.4 \mathrm{~Hz}, 1 \mathrm{H}$, arom.) 8.55 (dd, $J=8.6,1.4 \mathrm{~Hz}, 1 \mathrm{H}$, arom.), 8.15 (br s, $\left.0.6 \mathrm{H}, \mathrm{Me}_{2} \mathrm{NH}_{2}\right), 7.89-7.83$ (m, $2 \mathrm{H}$, arom.), 6.83 (br s, $0.6 \mathrm{H}, \mathrm{Me}_{2} \mathrm{NH}_{2}$ ), 5.54 (AB, $\left.J=12.3 \mathrm{~Hz}, 4 \mathrm{H}, \mathrm{CH} \mathrm{OV}\right), 3.19-3.15$ (m, 38.8H, N( $\left.\mathrm{CH}_{2} \mathrm{CH}_{2} \mathrm{CH}_{2} \mathrm{Me}_{4}\right)$ and $\left.\mathrm{Me}_{2} \mathrm{NH}_{2}\right), 2.02\left(\mathrm{q}, J=7.5 \mathrm{~Hz}, 2 \mathrm{H}, \mathrm{CH}_{2} \mathrm{Me}\right), 1.62-1.54\left(\mathrm{~m}, 37.6 \mathrm{H}, \mathrm{N}\left(\mathrm{CH}_{2} \mathrm{CH}_{2} \mathrm{CH}_{2} \mathrm{Me}\right)_{4}\right), 1.37-1.28(\mathrm{~m}, 40.6 \mathrm{H}$, $\mathrm{N}\left(\mathrm{CH}_{2} \mathrm{CH}_{2} \mathrm{CH}_{2} \mathrm{Me}\right)_{4}$ and $\left.\mathrm{CH}_{2} \mathrm{Me}\right), 0.95-0.92\left(\mathrm{~m}, 56.4 \mathrm{H}, \mathrm{N}\left(\mathrm{CH}_{2} \mathrm{CH}_{2} \mathrm{CH}_{2} \mathrm{Me}\right)_{4}\right)$. ${ }^{13} \mathrm{C}$ NMR $\left(100 \mathrm{MHz}, \mathrm{d}_{6}-\mathrm{DMSO}\right): \delta=$ 178.2 (C=O), 151.3 ( $\mathrm{CH}$ arom.), 144.4 (C arom.), 140.4 (CH arom.), 139.6 (CH arom.), 136.5 (CH arom.), 128.1 (C arom.), 126.8 (CH arom.), 122.6 (CH arom.), 121.4 (C arom.), $88.7 \quad\left(\mathrm{CH}_{2} \mathrm{OV}\right), \quad 62.9 \quad(C \mathrm{NH}), \quad 59.2$ $\left(\mathrm{N}\left(\mathrm{CH}_{2} \mathrm{CH}_{2} \mathrm{CH}_{2} \mathrm{Me}\right)_{4}\right), 35.7\left(\mathrm{Me}_{2} \mathrm{NH}_{2}\right), 28.5\left(\mathrm{CH}_{2} \mathrm{Me}\right), 23.1\left(\mathrm{~N}\left(\mathrm{CH}_{2} \mathrm{CH}_{2} \mathrm{CH}_{2} \mathrm{Me}\right)_{4}\right), 19.2\left(\mathrm{~N}_{(}\left(\mathrm{CH}_{2} \mathrm{CH}_{2} \mathrm{CH}_{2} \mathrm{Me}\right)_{4}\right), 13.5$ $\left(\mathrm{N}\left(\mathrm{CH}_{2} \mathrm{CH}_{2} \mathrm{CH}_{2} \mathrm{Me}\right)_{4}\right), 7.2\left(\mathrm{CH}_{2} \mathrm{Me}\right) .{ }^{31} \mathrm{P} \mathrm{NMR}\left(162 \mathrm{MHz}, \mathrm{CD}_{3} \mathrm{CN}\right) \delta=-5.69(\mathrm{~s}, 1 \mathrm{P}),-11.80$ (s, 1P). Anal. calc. for $\mathrm{TBA}_{4.7}\left(\mathrm{Me}_{2} \mathrm{NH}_{2}\right)_{0.3} \mathrm{C}_{15} \mathrm{H}_{16} \mathrm{~N}_{2} \mathrm{O}_{62} \mathrm{P}_{2} \mathrm{~V}_{3} \mathrm{~W}_{15}\left(5342.21\right.$ g.mol $\left.{ }^{-1}\right)$ : C 20.41, H 3.54, N 1.83; found: C 20.64, H 3.42, N 1.87.

\subsection{Palladacycle 20}

POM 15 (100 mg, 0.019 mmol, 1 equiv.) and $\mathrm{Pd}(\mathrm{OAc})_{2}$ (4 mg, $0.019 \mathrm{mmol}, 1$ equiv.) were dissolved in $\mathrm{CD}_{3} \mathrm{CN}$ and transferred in a sealed tube. The mixture was stirred for $5 \mathrm{~min}$ at $\mathrm{rt}$ and treated as in GP1 to afford the pure functionalized POM 20 (91 mg, 0.017 mmol, 89\% yield). IR: v = 2963, 1581, 1484, 1382, 1087, 1052, 1024, 951, 904, $811,734 \mathrm{~cm}^{-1} .{ }^{1} \mathrm{H}$ NMR (400 MHz, d $\mathrm{d}_{6}$-DMSO): $\delta=8.26$ (br s, $1 \mathrm{H}$, arom.), 8.10 (br s, $1 \mathrm{H}$, arom.), 8.01 (d, $J=8.1 \mathrm{~Hz}$, $1 \mathrm{H}$, arom.), 7.76 (br s, $1 \mathrm{H}$, arom.), 7.20 (m, 3H, arom.), 5.71 (A of $\mathrm{AB}, J=11.8 \mathrm{~Hz}, 2 \mathrm{H}, \mathrm{CHHOV}), 5.44$ (B of $\mathrm{AB}, J=$ $11.8 \mathrm{~Hz}, 2 \mathrm{H}, \mathrm{CHHOV}), 4.24$ (br s, $1 \mathrm{H}, \mathrm{CHNH}), 3.18-3.16\left(\mathrm{~m}, 38.4 \mathrm{H}, \mathrm{N}\left(\mathrm{CH}_{2} \mathrm{CH}_{2} \mathrm{CH}_{2} \mathrm{Me}\right)_{4}\right), 1.58-1.56(\mathrm{~m}, 38.4 \mathrm{H}$, $\left.\mathrm{N}\left(\mathrm{CH}_{2} \mathrm{CH}_{2} \mathrm{CH}_{2} \mathrm{Me}\right)_{4}\right), 1.34-1.30\left(\mathrm{~m}, 38.4 \mathrm{H}, \mathrm{N}\left(\mathrm{CH}_{2} \mathrm{CH}_{2} \mathrm{CH}_{2} \mathrm{Me}\right)_{4}\right), 0.94-0.92\left(\mathrm{~m}, 57.6 \mathrm{H}, \mathrm{N}\left(\mathrm{CH}_{2} \mathrm{CH}_{2} \mathrm{CH}_{2} \mathrm{Me}\right)_{4}\right) .{ }^{13} \mathrm{C}$ NMR (100 MHz, d 6 -DMSO): $\delta=175.0(\mathrm{C}=\mathrm{O}), 164.1$ (C arom.), 151.2 (C arom.), 146.5 (C arom.), 141.7 ( $\mathrm{CH}$ arom.), 133.5 (CH arom.), 130.6 ( $\mathrm{CH}$ arom.), 126.1 ( $\mathrm{CH}$ arom.), 125.4 ( $\mathrm{CH}$ arom.), 124.6 ( $\mathrm{CH}$ arom.), 121.5 ( $\mathrm{CH}$ arom.),

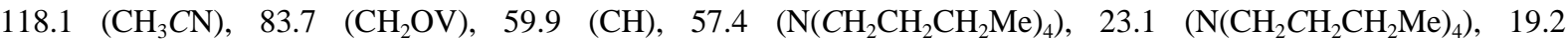
$\left(\mathrm{N}\left(\mathrm{CH}_{2} \mathrm{CH}_{2} \mathrm{CH}_{2} \mathrm{Me}\right)_{4}\right), 13.5\left(\mathrm{~N}\left(\mathrm{CH}_{2} \mathrm{CH}_{2} \mathrm{CH}_{2} \mathrm{Me}\right)_{4}\right) 0.7\left(\mathrm{CH}_{3} \mathrm{CN}\right){ }^{31} \mathrm{P} \mathrm{NMR}\left(162 \mathrm{MHz}, \mathrm{CD}_{3} \mathrm{CN}\right) \delta=-5.99(\mathrm{~s}, 1 \mathrm{P})$, 11.96 (s, 1P). Anal. calc. for $\mathrm{TBA}_{4.8} \mathrm{H}_{0.2} \mathrm{C}_{15} \mathrm{H}_{12} \mathrm{~N}_{2} \mathrm{O}_{62} \mathrm{PdP}_{2} \mathrm{~V}_{3} \mathrm{~W}_{15}\left(5348.80\right.$ g.mol ${ }^{-1}$ ): C 20.61, H 3.48, N 1.78; found: C 20.82, H 3.48, N 1.85 .

\subsection{Heck reaction}

Iodobenzene ( $110 \mu \mathrm{L}, 1 \mathrm{mmol}, 1$ equiv.) was added to a mixture of styrene ( $228 \mu \mathrm{L}, 2 \mathrm{mmol}, 2$ equiv.), the POM catalyst (0.01 mmol, 0.01 equiv.) and $\mathrm{Na}_{2} \mathrm{CO}_{3}\left(127 \mathrm{mg}, 1.2 \mathrm{mmol}, 1.2\right.$ equiv.) or $\mathrm{Et}_{3} \mathrm{~N}$ (162 $\mu \mathrm{L}, 1.2 \mathrm{mmol}, 1.2$ equiv.) in $0.5 \mathrm{~mL}$ of DMF, DMSO or $\mathrm{CH}_{3} \mathrm{CN}$. The solution was over after $20 \mathrm{~h}$ at $80{ }^{\circ} \mathrm{C}$.

\section{Acknowledgments}

We thank Université P. et M. Curie (UPMC), CNRS and ANR (grant number 08-PCVI-0005 to E. L., S. T. and B. H.) for funding. FR2769 is acknowledged for technical assistance.

\section{References and notes}

1. a) Hill C. L. In Comprehensive Coordination Chemistry II;Wedd, A. G., Ed.; Elsevier: Oxford, 2004; Vol. 4, pp 679-759; b) Pope M. T. In Comprehensive Coordination Chemistry II;Wedd, A. G., Ed.; Elsevier: Oxford, 2004; Vol. 4, pp 635-678; c) Proust, A.; Thouvenot, R.; Gouzerh P. Chem. Commun. 2008; 1837-1852; e) Dolbecq, A.; Dumas, E.; Mayer, C. R.; Mialane P. Chem. Rev. 2010, 110, 6009-6048; f) Long, D.-L.; Tsunashima, R.; Cronin L. Angew. Chem. Int. Ed. 2010, 49, 1736-1758; g) Oms O.; Dolbecq, A.; Mialane, P. Chem. Soc. Rev. 2012, 41, 7497-7536.

2. Putaj, P.; Lefebvre, F. Coord. Chem. Rev. 2011, 255, 1642-1685; b) Izarova, N.; Pope, M. T.; Kortz, U. Angew. Chem. Int. Ed. 2012, 51, 9492-9510.

3. Knoth, W. H.; Domaille, P. J.; Harlow, R. L. Inorg. Chem. 1986, 25, 1577-1584.

4. Angus-Dunne, S.; Burns, R. C.; Craig, D. C.; Lawrance, G. A. J. Chem. Soc. Chem. Commun. 1994, 4, 523-524. 
5. a) Kurata, T.; Uehara, A.; Hayashi, Y.; Isobe, K. Inorg. Chem. 2005, 44, 2524-2530; b) Villanneau, R.; Renaudineau, S.; Herson, P.; Boubekeur, K.; Thouvenot, R.; Proust A. Eur. J. Inorg. Chem. 2009, 479-488; c) Angus-Dunne, S.; Burns, R. C.; Craig, D. C.; Lawrance, G. A. Z. Anorg. Allg. Chem. 2010, 636, 727-734; d) Hirano, T.; Uehara, K.; Kamata, K.; Mizuno, N. J. Am. Chem. Soc. 2012, 134, 6425; e) Duval, S.; Marrot, J.; Simonnet-Jégat, C.; Mbomekallé, I. M.; Sokolov, M.; Cadot, E. Dalton Trans. 2012, 41, 3174-3184.

6. a) Bi, L.-H.; Reicke, M.; Kortz, U.; Keita, B.; Nadjo, L.; Clark, R. J. Inorg Chem. 2004, 43, 3915-3920; b) Bi, L.-H.; Kortz, U.; Keita, B.; Nadjo, L.; Borrmann H. Inorg Chem. 2004, 43, 8367 -8372; c) Bi, L.-H.; Kortz, U.; Keita, B.; Nadjo, L.; Daniels L. Eur. J. Inorg. Chem. 2005, 3034-3041; d) Bi, L.-H.; Dickman, M. H.; Kortz, U. CrystEngComm 2009, 11, 965-966; e) Izarova, N. V.; Banerjee, A.; Kortz, U. Inorg. Chem. 2011, 50, 10379-10386.

7. Favette, S.; Hasenknopf, B.; Vaissermann, J.; Gouzerh, P.; Roux, C. Chem Commun 2003, 21, $2664-2665$.

8. Bar-Nahum, I.; Cohen, H.; Neumann, R. Inorg. Chem. 2003, 42, 3677-3684.

9. a) Berardi, S.; Carraro, M.; Iglesias, M.; Sartorel, A.; Scorrano, G.; Albrecht, M.; Bonchio, M. Chem. Eur. J. 2010, 16, 1066210666; b) Santoni, M.-P.; Pal, A. K.; Hanan, G. S.; Proust, A.; Hasenknopf, B. Inorg. Chem. 2011, 50, 6737-6745; c) Santoni, M.-P.; Pal, A. K.; Hanan, G. S.; Tang, M.-C.; Venne, K.; Furtos, A; Ménard-Tremblay, P.; Malveau, C.; Hasenknopf, B. Chem. Commun. 2012, 48, 200-202.

10. Ettedgui, J.; Neumann, R. J. Am. Chem. Soc. 2009, 131, 4-5.

11. Zhao, P.; Leng, Y.; Zhang, M.; Wang, J.; Wu, Y.; Huang, J. Chem. Commun. 2012, 48, 5721-5723.

12. a) Boglio, C.; Lemière, G.; Hasenknopf, B.; Thorimbert, S.; Lacôte, E.; Malacria, M. Angew. Chem. Int. Ed. 2006, 45, 3324-3327; b) Boglio, C.; Micoine, K.; Rémy, P.; Hasenknopf, B.; Thorimbert, S; Lacôte, E.; Malacria, M.; Alfonso, C.; Tabet J.-C. Chem. Eur. J. 2007, 13, 5426-5432; c) Kikukawa, Y.; Yamaguchi, S.; Nakagawa, Y.; Uehara, K.; Uchida, S.; Yamaguchi., K.; Mizuno N. J. Am. Chem. Soc. 2008, 130, 15872-15878; d) Dupré, N.; Rémy, P.; Micoine, K.; Boglio, C.; Thorimbert, S.; Lacôte, E.; Hasenknopf, B.; Malacria M. Chem. Eur. J. 2010, 16, 7256-7264; e) El Moll, H.; Nohra, B.; Mialane, P.; Marrot, J.; Dupré, N.; Riflade, B.; Malacria, M.; Thorimbert, S.; Hasenknopf, B.; Lacôte, E.; Aparicio, P. A.; López, X.; Poblet, J. M.; Dolbecq A. Chem. Eur. J. 2011, 17, 14129-14138; f) Suzuki, K.; Sugawa, M.; Kikukawa, Y.; Kamata, K.; Yamaguchi, K.; Mizuno N. Inorg. Chem. 2012, 51, 6953-6961; g) Absillis, G.; Parac-Vogt T. N. Inorg. Chem. 2012, 51, 9902-9910; h) Vanhaecht, S.; Absillis, G.; Parac-Vogt T. N. Dalton Trans. 2012, 41, 10028-10034; i) Dupré, N.; Brazel, C.; Fensterbank, L.; Malacria, M.; Thorimbert, S.; Hasenknopf, B.; Lacôte, E. Chem. Eur. J. 2012, 18, 12962-12965.

13. Li J.; Huth, I.; Chamoreau, L.-M.; Hasenknopf, B.; Lacôte, E.; Thorimbert, S.; Malacria, M. Angew. Chem. Int. Ed. 2009, 48, 2035-2038.

14. Oble, J.; Riflade, B.; Noël, A.; Malacria, M.; Thorimbert, S.; Hasenknopf, B.; Lacôte E. Org. Lett. 2011, 13, $2990-5993$.

15. Riflade, B.; Oble, J.; Li, J.; Thorimbert, S.; Hasenknopf, B.; Lacôte, E. submitted.

16. For the preparation of diol amides see: a) Wybow, R. A. J.; Edwards, A. S.; Stevenson, N. G.; Adams, H.; Johnstone, G.; Harrity, P. A. Tetrahedron 2004, 60, 8869; b) Adachi, K.; Kohara, N.; Nakao, N.; Arita, M.; Chiba, K.; Mishina, T.; Sasaki, S.; Fujita, T. Biorg. Med. Chem. Lett. 1995, 5, 853 .

17. Zaitsev, V. D.; Shabashov, D.; Daugulis, O. J. Am. Chem. Soc. 2005, 127, 13154-13155.

18. For recent references, see: a) Juliá-Hernández, F.; Arcas, A.; Vicente, J. Chem. Eur. J. 2012, 18, 7780-7786; b) Sumimoto, M.; Kuroda, T.; Yokogawa, D.; Yamamoto, H.; Hori, K. J. Organomet. Chem. 2012, 710, 26-35; c) Sundermann, A.; Uzan, O.; Martin, J. M. L. Chem. Eur. J. 2001, 7, 1703-1711. For a review, see: d) Sehnal, P.; Taylor, R. J. K.; Fairlamb, I. J. S. Chem. Rev. 2010, 110, 824-889.

19. Selander, N.; Szabò, K. J. Chem. Rev. 2011, 11, 2048-2076 ; b) Sommer, W. J.; Yu, K.; Sears, J. S.; Ji, Y.; Zheng, X.; Davis, R. J.; Sherrill, C. D.; Jones, C. W.; Weck, M. Organometallics 2005, 24, 4351-4361; b) Nilsson, P.; Wendt, O. F. J. Organomet. Chem. 2005, 690, 4197-4202; c) Da Costa, R. C.; Jurisch, M.; Gladysz, J. A. Inorg. Chim. Acta 2008, 361, 3205-3214; d) Suijkerbuijk, B. M. J. M.; Martinez, S. D. H.; van Koten, G.; Klein Gebbink, R. J. M. Organometallics 2008, $27,534-542$.

20. Ahlrichs, R.; Bär, M.; Häser, M.; Horn, H.; Kölmel, C. Chem. Phys. Lett. 1989, 162, 165-169.

21. Treutler, O.; Ahlrichs, R. J. Chem. Phys. 1995, 102, 346-354.

22. F. Weigend, F.; Häser, M.; Patzelt, H.; Ahlrichs, R. Chem. Phys. Lett. 1998, 294, 143-152.

23. Boglio, C.; Micoine, K.; Derat, E.; Thouvenot, R.; Hasenknopf, B.; Thorimbert, S.; Lacôte, E.; Malacria, M. J. Am. Chem. Soc. 2008, 130, 4553-4561.

24. Finke, R. G.; Rapko, B.; Saxton, R. J.; Domaille, P. J. J. Am. Chem. Soc. 1986, 108, 2947-2960.

25. a) Malkov, A. V. ; Hand, J. B. ; Kocovsky, P. Chem. Commun, 2003, 15, 1948-1949 ; b) Tse, M. K. ; Jiao, H. ; Anilkumar, G. ; Bitterlich, B. ; Gelalcha, F. G. ; Beller, M. J. Org. Chem. 2006, 691, 4419-4433.

\section{Supplementary Material}

NMR spectra of new compounds. 